\title{
Application of the FT-IR/PAS and DRS Methods for Studying Heavy Metal Ions Sorption on the Inorganic Sorbents
}

\author{
P. Rusek ${ }^{a, *}$, Z. Hubicki ${ }^{b}$, G. WójciK ${ }^{b}$ And A. Debczak ${ }^{c}$ \\ ${ }^{a}$ Fertilizers Research Institute, al. 1000-lecia Państwa Polskiego 13a, 24-100 Puławy, Poland \\ ${ }^{b}$ Department of Inorganic Chemistry, ${ }^{c}$ Department of Chemical Technology \\ University of Maria Curie-Skłodowska, Pl. M. Curie-Skłodowskiej 3, 20-031 Lublin, Poland
}

\begin{abstract}
The scope of this study was the removal of heavy metal ions, ammonium and organic substances by ion exchange from municipal wastewaters. Clinoptilolite, bentonite, and palygorskite are especially interesting in the group of inorganic sorbents because of their specific physico-chemical properties. Specific surface areas and pore distributions were determined for the above sorbents. Sorption kinetics of $\mathrm{Zn}(\mathrm{II}), \mathrm{Cu}(\mathrm{II}), \mathrm{Ni}(\mathrm{II})$, $\mathrm{Pb}$ (II) and ammonium ions in synthetic solutions and wastewaters were investigated on the above sorbents. Ion sorption process was carried out with a static method at various phase contact times. The atomic adsorption spectroscopy method was used for measurements of heavy metal contents. The adsorption process was found to be $\mathrm{pH}$ and concentration dependent. The removal mechanism of metal ions was by adsorption and ion exchange processes. The FT-IR photoacoustic spectroscopy method was used to study mechanism of $\mathrm{Zn}$ (II), $\mathrm{Cu}(\mathrm{II}), \mathrm{Ni}(\mathrm{II}), \mathrm{Pb}(\mathrm{II})$ and ammonium ions sorption on the clinoptilolite, bentonite and palygorskite. The spectra of FT-IR/PAS before and after sorption of $\mathrm{Zn}(\mathrm{II}), \mathrm{Cu}(\mathrm{II}), \mathrm{Ni}(\mathrm{II}), \mathrm{Pb}(\mathrm{II})$ and ammonium ions were investigated.
\end{abstract}

PACS numbers: $82.80 . \mathrm{Kq}, 81.70 . \mathrm{Cv}, 82.50 .-\mathrm{m}$

\section{Introduction}

Growing pollution of surface underground water with simultaneously increasing demand for water of high quality parameters requires finding efficient and ecologically safe methods of water and sewage treatment. Municipal wastewaters may contain heavy metals such as $\mathrm{Ni}, \mathrm{Cu}$, $\mathrm{Zn}, \mathrm{Pb}$ etc. and organic substances. The toxic metals, existing in high concentrations (even up to $400 \mathrm{mg} / \mathrm{dm}^{3}$ ), must be effectively treated from wastewaters. If wastewaters were discharged directly into natural water, it would constitute a great risk for the aquatic ecosystem, whilst the direct discharge into the sewage system might affect negatively the subsequent biological wastewater treatment [1]. Ion exchange and adsorption methods are used most frequently for removal of heavy metal ions from wastewater. In the last 20 years, characteristics of natural zeolites have been intensively studied for the needs of wastewater treatment [2-11]. Natural sorbents are increasingly widely used in wastewater purification processes due to their frequent occurrence in nature, low cost as compared with synthetic materials, remarkable properties with respect to adsorption capacity, molecular sieve properties, high selectivity for heavy metal ions, and resistance to acid and high temperature. The present study demonstrates that natural sorbents of various types, as

* corresponding author; e-mail: prusek@ins.pulawy.pl well as adsorption-active materials based thereon, can be readily used for removal of heavy metal ions, organic substances from wastewaters.

\section{Experimental}

\subsection{Characteristics of sorbents}

Bentonite, clinoptilolite, palygorskite were ground and sieved to fractions. The samples were washed with distilled water to remove turbidity and dried at room temperature (air-drying). The fraction commonly used in test is in the range $0.3-0.5 \mathrm{~mm}$. Results in Tables refer to sorbents of particle size $0.3-0.5 \mathrm{~mm}$. X-ray fluorescency spectroscopy with X-Unique II Philips apparatus was used for chemical composition analysis. The chemical composition of the mineral is shown in Table I. Development of specific surface areas was determined with Brunauer-Emmett-Teller (BET) method using Sorptomatic Fisions apparatus. Porosity was determined with mercury porometric method. The physical characteristics of the minerals is shown in Table II. The waste samples were collected from the wastewater treatment plant of Puławy in Poland.

\subsection{Sorption investigation}

In all the experiments carried out, $10 \mathrm{~g}$ of each sorbent was placed in contact with $100 \mathrm{ml}$ of wastewater solution in $250 \mathrm{ml}$ Erlenmayer flasks. For each experiment, one sample was reserved for the analysis to 
TABLE I

Chemical compositions of the natural sorbents used.

\begin{tabular}{c|c|c|c}
\hline \hline Constituents [\%] & Clinoptilolite & Palygorskite & Bentonite \\
\hline $\mathrm{SiO}_{2}$ & 42.4 & 65.3 & 65.6 \\
$\mathrm{Al}_{2} \mathrm{O}_{3}$ & 15.3 & 13.7 & 19.8 \\
$\mathrm{Fe}_{2} \mathrm{O}_{3}$ & 1.7 & 9.8 & 9 \\
$\mathrm{MgO}$ & 0.5 & 8.2 & 1.8 \\
$\mathrm{CaO}$ & 2.01 & 0.8 & 1.5 \\
$\mathrm{~K}_{2} \mathrm{O}$ & 4.02 & 1.24 & 0.13 \\
$\mathrm{Na}_{2} \mathrm{O}$ & 0.21 & 0.1 & 0.06 \\
$\mathrm{TiO}_{2}$ & 0.12 & 0.47 & 1.78 \\
$\mathrm{MnO}_{\mathrm{Cr}} \mathrm{O}_{3}$ & - & 0.17 & $<0.004$ \\
$\mathrm{NiO}$ & - & 0.01 & 0.03 \\
& - & 0.06 & 0.03
\end{tabular}

TABLE II

Physical characteristics of the investigated sorbents.

\begin{tabular}{l|c|c|c}
\hline \hline Parameters & Clinoptilolite & Palygorskite & Bentonite \\
\hline $\begin{array}{l}\text { total cumulative } \\
\text { vol. }\left[\mathrm{mm}^{3} / \mathrm{g}\right]\end{array}$ & 195.27 & 287.67 & 157.7 \\
\hline $\begin{array}{l}\text { specific surface } \\
\text { area }\left[\mathrm{m}^{2} / \mathrm{g}\right]\end{array}$ & 31.12 & 268.2 & 62.57 \\
\hline $\begin{array}{l}\text { pore radius } \\
\text { average }[\mathrm{nm}]\end{array}$ & 26 & 7 & 5 \\
\hline bulk density & 1.65 & 1.41 & 5 \\
\hline $\begin{array}{l}\text { correc. bulk } \\
\text { density }\left[\mathrm{g} / \mathrm{cm}^{3}\right]\end{array}$ & 2.43 & 2.37 & 3 \\
\hline \begin{tabular}{l} 
porosity $[\%]$ \\
\hline
\end{tabular} & 32.22 & 40.56 & 32.18
\end{tabular}

measure the initial value. The ion concentrations before the sorption process were: $\mathrm{Cu}(\mathrm{II})-94 \mathrm{mg} / \mathrm{dm}^{3}$, $\mathrm{Zn}(\mathrm{II})-128 \mathrm{mg} / \mathrm{dm}^{3}, \mathrm{Ni}(\mathrm{II})-25 \mathrm{mg} / \mathrm{dm}^{3}, \mathrm{~Pb}(\mathrm{II})-$ $12 \mathrm{mg} / \mathrm{dm}^{3}, \mathrm{NH}_{4}^{+}-650 \mathrm{mg} / \mathrm{dm}^{3}$. After the equilibrium contact time $(30 \mathrm{~min})$, the samples were filtered off at the end of the process through a $0.2 \mu \mathrm{m}$ pore size Millipore filter. The atomic adsorption spectroscopy (AAS) - Varian 240 FS method was used for measurements of heavy metal contents.

\subsection{Spectroscopic investigations}

The FT-IR photoacoustic (FT-IR/PA) spectra were recorded by means of a Bio-Rad Excalibur 3000MX spectrometer equipped with a photoacoustic detector MTEC 300 over the $4000-400 \mathrm{~cm}^{-1}$ range at the resolution of $4 \mathrm{~cm}^{-1}$ and maximum source aperture. The spectra were normalized with reference to the MTEC carbon black standard. Before each data collection the PAS cell was purged with dry helium for 5 min. Interferograms of 512 scans were averaged for each spectrum. The diffuse reflectance spectroscopy (DRS) spectra were measured by using the Specord M42 spectrometer equipped with a diffuse reflectance attachment produced by Carl Zeiss Germany. The spectra FT-IR/PAS and DRS before and after sorption of $\mathrm{Zn}(\mathrm{II}), \mathrm{Cu}(\mathrm{II}), \mathrm{Ni}(\mathrm{II}), \mathrm{Pb}(\mathrm{II})$ and ammonium ions were investigated.

\section{Results and discussion}

\subsection{The FT-IR/PAS method}

In the spectra of bentonite (Fig. 1) between 3650 and $3300 \mathrm{~cm}^{-1}$ there exist signals related to vibrations of $-\mathrm{OH}$ groups which are present in minerals as hydroxyl groups, water traces, and hydroxonium ion $\left(\mathrm{H}_{3} \mathrm{O}^{+}\right)$. The peak characteristic of stretching vibration of $\mathrm{Al}(\mathrm{Mg})-\mathrm{OH}$ was observed at $3364 \mathrm{~cm}^{-1}$. The band of zeolitic water occurs in the range $3550-3350 \mathrm{~cm}^{-1}$. Zeolitic and adsorbed water gives an asymmetric signal at $1650 \mathrm{~cm}^{-1}$. The signals at 1050 and $997 \mathrm{~cm}^{-1}$ correspond to $\mathrm{Si}-\mathrm{O}$ stretching bond vibrations. The $\mathrm{Al}-\mathrm{Al}-\mathrm{O}$ groups deformation gives a peak at $914 \mathrm{~cm}^{-1}$. At $879 \mathrm{~cm}^{-1}$ the $\mathrm{Fe}-\mathrm{Al}-\mathrm{O}$ deformation signal is found and after sorption of heavy metals the signal is divided into 889 and $875 \mathrm{~cm}^{-1}$. The twisting vibrations at $628 \mathrm{~cm}^{-1}$ of $\mathrm{Al}-\mathrm{OH}, \mathrm{Si}-\mathrm{O}$ groups disappear after heavy metal ions sorption. The PAS results show two signals at 2939 and $2858 \mathrm{~cm}^{-1}$ which are related to organic substances. Bentonite (after sorption process) gives the strongest signal, it also worked on the spectrum of other sorbents but in a weaker way. This fact indicates that bentonite is more flexible for sorption of organic wastes than clinoptilolite (Fig. 2) and palygorskite.

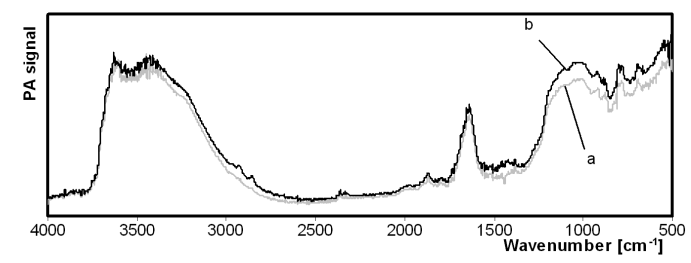

Fig. 1. The FT-IR/PA spectra of bentonite before (a) and after (b) ions sorption process.

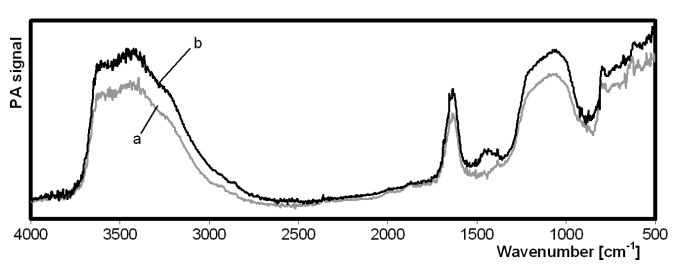

Fig. 2. The FT-IR/PA spectra of clinoptilolite before (a) and after (b) ions sorption process.

The FT-IR/PA spectra of palygorskite are shown in Fig. 3. The peak at $3616 \mathrm{~cm}^{-1}$ corresponds to $\mathrm{OH}$ (hydrooxide) stretching vibrations of $\mathrm{Al}-\mathrm{Al}-\mathrm{OH}$ group and is characteristic of bentonite and palygorskite minerals. The low intensity peak at $3583 \mathrm{~cm}^{-1}$ is shifted 


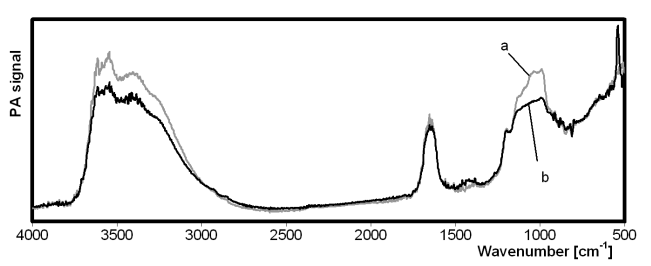

Fig. 3. The FT-IR/PA spectra of palygorskite before (a) and after (b) ions sorption process.

after wastewater sorption. This effect might suggest that wastes are sorbed not only on the surface but are blocked in palygorskite channels. The peak in the range $3550-3350 \mathrm{~cm}^{-1}$ corresponds to vibrations of zeolitic and coordination water. The asymmetric signal at $1650 \mathrm{~cm}^{-1}$ corresponds to bending vibrations of zeolitic and adsorbed water. This signal is more split at $1647,1656 \mathrm{~cm}^{-1}$ for clinoptylolite and palygorskite than for bentonite. In the palygorskite $\mathrm{PA}$ spectra the $\mathrm{Si}-\mathrm{O}$ stretching vibrations are split into $1039-989 \mathrm{~cm}^{-1}$ and after sorption of wastewater the band at $1039 \mathrm{~cm}^{-1}$ disappears. This phenomenon occurs only for palygorskite.

\subsection{The DRS method}

The bentonite was characterized by higher sorption capacity of heavy metal and ammonium ions than clinoptilolite and palygorskite, therefore the DRS spectra were measured for it. In Fig. 4 the DRS spectra were shown

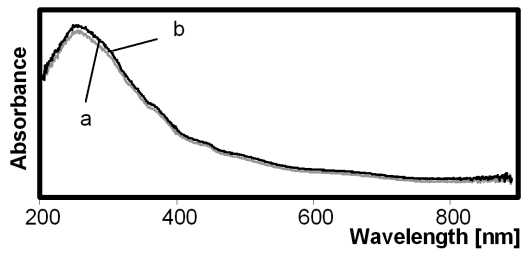

Fig. 4. The DRS spectra of bentonite before (a) and after (b) sorption of heavy metal and ammonium. before and after sorption process. There are no observed significant differences in the spectra. It was considered with low concentration of sorbed heavy metal ions in the solid phase and the wastewaters. This method is not sensitive enough in the investigated concentration region.

\section{Conclusion}

The PAS method is very useful in investigations because it provides some important information related to the structures of bentonite, clinoptilolite and palygorskite before and after heavy metal and ammonium ions sorption. Moreover, the PAS method is more sensitive than DRS.

\section{References}

[1] K.S. Hui, C.Y.H. Chao, S.C. Kot, J. Hazard Mater. B 127, $89(2005)$

[2] J.H. Koon, W.J. Kaufman, : J. Water. Pollut. Fed. 47, 449 (1975).

[3] E. Czaran, A. Meszaros-Kis, E. Domokos, J. Papp. Nucl. Chem. Waste Manag. 8, 107 (1988).

[4] H.T. Dryden, L.R. Weatherley, Aquacult. Eng. 8, 109 (1989).

[5] B. Beler-Baykal, M. Oldenburg, I. Sekoulov, Environ. Technol. 28, 717 (1996).

[6] N.A. Booker, E.L. Priestley, A.J. Priestley, Water Sci. Technol. 34, 17 (1996).

[7] M.L. Nguyen, C.C. Tanner, J. Agr. Res. 41, 427 (1998).

[8] L. Curković, Š. Cerjan-Stefanović, T. Filipan, Water Res. 31, 1379 (1997)

[9] J. Mazur, B. Pustelny, Mol. Quant. Acoust. 28, 195 (2007).

[10] T. Starecki, Acta Phys. Pol. A 114, A-199 (2008).

[11] S. Babel, T.A. Kurniawan, J. Hazard. Mater. B 97, 219 (2003). 